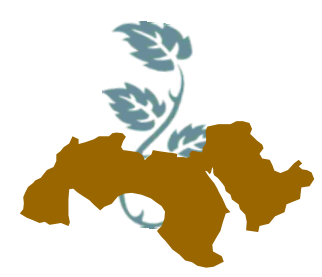

513

Arab Univ.

J. Agric. Sci., Ain Shams Univ., Cairo, 24(2), 513-523, 2016

\title{
PRODUCTION OF HEALTHY SNACKS FROM BARLEY, CHICKPEA, LETTUCE SEEDS AND HERB DISTRIBUTED IN EGYPT
}

\author{
Twfik $^{1}$, F.M.; A.M. Sulieman ${ }^{2}$; A.S. Barakat ${ }^{1}$; M.S. Abbas ${ }^{3}$ \\ and H.M. Sobhy ${ }^{3}$ \\ 1- Institute of Food Technology, Agriculture Research Center, Giza, Egypt \\ 2- Food Science Dept., Faculty of Agricultur, Zagazig University, Egypt \\ 3- Department of Natural Resources, Institute of African Research and Studies, Cairo \\ University, Giza, Egypt
}

Keywords: Barley; Chickpea; Cumin; Black cumin; Black pepper; Lettuce seeds and Snacks

\section{ABSTRACT}

Snacks was made from yellow corn and its blends had contained corn, barley, chickpea, cumin, black cumin, black pepper and lettuce seeds at different levels considerable as lettuce seeds of ingredient and products were defined as physical, chemical and sensory evaluation. The results showed that the chickpea had contained the highest in protein and total lipids 40.60 and $15.50 \%$. The black pepper, chickpea and cumin seeds had contained higher in crude fiber (14.20, 10.71 and $10.50 \%$, respectively). The snacks with lettuce seeds showed that the protein was the highest in group (2) it was 15.04, 16.44 and $17.82 \%$. Total lipids, crude fiber and ash content were decreased gradually in the snacks from group (1) 4.02, 4.87 and $5.72 \%$ and the highest in total lipids in group (2) which contained $4.23,5.08$ and $5.93 \%$, respectively. Hunter color values of snacks control and its different blends from lettuce seeds the group (6) prepared with $60 \%$ corn grits and 15,10 and $5 \%$ barley and also 6\% lettuce seeds showed that higher in lightness and yellowness till 15\% chickpea and nearly control snacks. The highest (WAI) and (WSI) were in groups (1 and 2) respectively made from $40 \%$ corn grits and $40,35,30$ and $25 \%$ barley. The sensory properties showed that the extrusion blend (18) made from $20 \%$ chickpea and $5 \%$ barley the highest acceptability (95\%) and nearly control (96\%) followed were by 10 and $15 \%$ chickpea plus 15 and $10 \%$ barley were gave 93.0 and $88.0 \%$ during overall acceptability.

\section{INTRODUCTION}

Food extruders provide thermo-mechanical and mechanical energy (shear) necessary to cause physicochemical changes of raw materials with an intense mixing for dispersion and homogenization of ingredients including conveying, mixing, shearing, heating or cooling, shaping, venting volatiles and moisture, flavor generation, encapsulation, and sterilization (Wiedman and Strobel, 1987). Advantages of this process is that one extruder can operate at relatively low temperatures and produce pasta and baking goods, or at very high temperatures, and then manufacture products with low bulk density, such as snacks and ready to eat cereals (Harper, 1981). In order to make products that will be acceptable in a very competitive market, extrusion of snack foods demands the control of many parameters that will directly or indirectly influence the consumer acceptability. Finished product characteristics are partly resulted from specific critical parameters induced in raw materials. The critical parameters that will partly affect the moisture, expansion, solubility, absorption, color, flavor and texture of the final product are (Huber, 2001): The chemistry of natural products interacts with different areas of expertise, and its relevance is linked to this interdisciplinary. Chemical studies of different plant species seed to detect 
information inherent to secondary metabolites and to contribute to the development of several areas of science. The use of plants by humans dates back thousands of years and relies on chance discoveries that are frequently proven by science. They were used to cure diseases, for food preservation and insect control. Many natural compounds present in plants, herbs and spices have shown biological activity and serve as a source of antimicrobial agents against various pathogens Simões et al (2007). The taste of a spice such as sweet, spicy, sour, or salty, is due to many different chemical components such as esters, phenols, acids, alcohols, chlorides, alkaloids, or sugars. Sweetness is due to esters and sugars; sourness to organic acids (citric, malic, acetic, or lactic); saltiness to cations, chlorides, and citrates; astringency to phenols and tannins; bitterness to alkaloids (caffeine and glycosides); and pungency to the acidamides, carbonyls, thiocyanates, and isothiocyanates (Raghavan, 2007). Theoretically, product darkening (developing a brown color) occurs due to the reducing sugars (e.g. liquid honey or glucose syrup) or an increase in the amount of reducing sugars available to participate in the Maillard reaction (Yilmaz and Toledo, 2005). The shelf life of intermediate moisture foods is often limited by Maillard reactions between the carbonyl groups of reducing carbohydrates and the exterior amine groups of proteins. Maillard reactions can lead to an unappealing texture, flavor, nutritional value and color of food products (Loveday et al 2010). The water absorption index (WAI) measures the volume occupied by the starch after swelling in excess water, and indicates the integrity of starch in aqueous dispersion. Water solubility index (WSI), often used as an indicator of degradation of molecular components, measures the degree of starch conversion during extrusion which is the amount of soluble polysaccharide released from the starch component after extrusion (Yang, 2008). Cumin seeds are used as a spice for their special aromatic effect, commonly in cuisines of India, Pakistan, North Africa, Middle East, Sri Lanka, Cuba, Northern Mexico and the Western China. Cumin seeds have been reportedly used for traditional treatment of toothache, dyspepsia, diarrhea, epilepsy and jaundice (Nostro et al 2005). Snacks made from corn containing corn as the only in gradient are poor in nutritional value. So the present study aims to evaluate of new blends from seed, grain and herbs to produce healthy snacks in Egypt.

\section{MATERIALS AND METHODS}

\section{Materials}

Hull less barley seeds (Hordeum vulgare) cultivar Giza 130, chickpea seeds (Glycine max) and yellow corn (Zea mays) were obtained from Field Crops Res. Inst., Agric. Res. Center, Giza-Egypt. Whereas, commercial cumin (Cuminum cyminum), black cumin (Nigella sativa), black pepper (Peper nigrum) and lettuce seeds (Lactuca sativa) were obtained from Horticulture Res. Inst., Agric. Res. Center, Giza-Egypt. Yellow corn, barley, chickpea, cumin, black cumin, black pepper and lettuce seeds were milled in a Laboratory Mill Junior to a fine powder were packaged in polyethylene bags and stored in refrigerator at (4-7) ${ }^{\circ} \mathrm{C}$, then submitted to the production and analysis.

\section{Methods}

Protein, total lipids, crude fiber and ash content and While total carbohydrates were estimated by subtracting the difference from initial weight of the samples as follow: \% carbohydrates = 100(\%moisture $+\%$ protein $+\%$ fat $+\%$ ash $+\%$ fiber $)$ AOAC. (2005). Total dietary fiber was determined by the methods described by Prosky (1988). Soluble and non-soluble dietary fiber was determined according to Lee and Prosky (1995).

\section{Preparation of the snack blends}

Control extruded puff snack was made from yellow corn grits only and the other blends had contained corn grits, barley, chickpea, cumin, black cumin, black pepper and lettuce seeds at different levels to give control and six groups ( 3 blends for each) to give nineteen blends.

\section{Extrusion of different snack blends}

The flour blend was separately adjusted to $18 \%$ moisture content (MC) by water addition through material balance (Nwabueze and Iwe, 2010). The prepared samples were extruded at selected constant extrusion condition: screw speed of 140rpm and barrel temperature of $140^{\circ} \mathrm{C}$ in a Brabender laboratory single-screw extruder (Duisburg DCE 330 , New Jersey USA) fitted with $2 \mathrm{~mm}$ die nozzle. The extruder had grooved barrel length to diameter (L/D) ratio of $20: 1$ fitted with $2 \mathrm{~mm}$ die nozzle diameter operated at a constant screw speed of 140rpm and $140^{\circ} \mathrm{C}$ barrel temperature. Compression ratio 
Table 1. Formulae of snack blends

\begin{tabular}{|c|c|c|c|c|c|c|c|c|}
\hline Group & No & $\begin{array}{c}\text { Corn } \\
\%\end{array}$ & $\begin{array}{c}\text { Barley } \\
\%\end{array}$ & $\begin{array}{c}\text { Chickpea } \\
\%\end{array}$ & $\begin{array}{c}\text { Lettuce } \\
\%\end{array}$ & $\begin{array}{c}\text { Cumin } \\
\%\end{array}$ & $\begin{array}{c}\text { Black } \\
\text { pepper } \\
\%\end{array}$ & $\begin{array}{c}\text { Black } \\
\text { cumin } \\
\% \\
\end{array}$ \\
\hline \multicolumn{2}{|c|}{ Control } & 100 & - & - & - & - & - & - \\
\hline \multirow{3}{*}{1} & 1 & 40 & 40 & 10 & 4 & 2 & 2 & 2 \\
\hline & 2 & 40 & 35 & 15 & 4 & 2 & 2 & 2 \\
\hline & 3 & 40 & 30 & 20 & 4 & 2 & 2 & 2 \\
\hline \multirow{3}{*}{2} & 4 & 40 & 35 & 10 & 6 & 3 & 3 & 3 \\
\hline & 5 & 40 & 30 & 15 & 6 & 3 & 3 & 3 \\
\hline & 6 & 40 & 25 & 20 & 6 & 3 & 3 & 3 \\
\hline \multirow{3}{*}{3} & 7 & 50 & 30 & 10 & 4 & 2 & 2 & 2 \\
\hline & 8 & 50 & 25 & 15 & 4 & 2 & 2 & 2 \\
\hline & 9 & 50 & 20 & 20 & 4 & 2 & 2 & 2 \\
\hline \multirow{3}{*}{4} & 10 & 50 & 25 & 10 & 6 & 3 & 3 & 3 \\
\hline & 11 & 50 & 20 & 15 & 6 & 3 & 3 & 3 \\
\hline & 12 & 50 & 15 & 20 & 6 & 3 & 3 & 3 \\
\hline \multirow{3}{*}{5} & 13 & 60 & 20 & 10 & 4 & 2 & 2 & 2 \\
\hline & 14 & 60 & 15 & 15 & 4 & 2 & 2 & 2 \\
\hline & 15 & 60 & 10 & 20 & 4 & 2 & 2 & 2 \\
\hline \multirow{3}{*}{6} & 16 & 60 & 15 & 10 & 6 & 3 & 3 & 3 \\
\hline & 17 & 60 & 10 & 15 & 6 & 3 & 3 & 3 \\
\hline & 18 & 60 & 5 & 20 & 6 & 3 & 3 & 3 \\
\hline
\end{tabular}

screw was A 4:1 (Nwabueze, 2007). Temperature settings were adjusted using thermostat at 120 , 150,170 and $220^{\circ} \mathrm{C}$. The extruder was allowed to run to stabilization at a screw speed of 140rpm using corn flour before the experimental runs commenced. The feed was introduced gradually but continuously to feed hopper equipped with an auxiliary anger screw at $300 \mathrm{~g} / \mathrm{min}$ and received at the die end as strands of pellets. The samples were stored at room temperature $\left(25 \pm 5^{\circ} \mathrm{C}\right)$. till analysis.

\section{Physical properties of different snack blends}

Color of dried snack blends were evaluated using a Hunter Lab. model D 25 according to Francis (1998). Water absorption index (WAl) and water solubility index (WSI) were determined according to the method of Anderson et al (1969). The texture profile analysis (TPA) index of different snacks blends were determined using a texture analyzer (Cometech, B type, Taiwan) according to Bourne (2003). Organoleptic properties such as appearances, crispiness, mouth-fell, flavor and Overall acceptability were evaluated in different snack blends with lettuce seeds by (10) will trained pan- elist of stuff member Ahmed, (1999). Statistical analyses were carried out using F-test for significance at $\mathrm{P} \leq 0.05$ and computing of "Least Significant Difference (L.S.D.)" test, values to separate means in different statistical groups according to described method by Gomez and Gomez (1984).

\section{RESULTS AND DISCUSSION}

\section{Chemical composition of raw materials}

Data presented in Table (2) show the protein, total lipids, crude fiber, ash content and total carbohydrates were determined in corn grits, barley, chickpea, lettuce seeds, cumin, black pepper and black cumin From the results in Table (2), it could be noticed that the chickpea had the highest content in protein content $40.60 \%$ followed by lettuce seeds, black cumin were $22.50,21.34$ respectively. Meanwhile cumin had contained the medium content in protein $17.81 \%$ followed by black pepper, barley and corn grits $12.50,12.01$ and $9.50 \%$ respectively. Data in Table (2) showed that the chickpea and lettuce seeds were higher value in total lipid (19.50 and $7.50 \%$ ) than black cumin, black pepper, barley, cumin and corn grits were 
Table 2. Chemical composition of raw materials

\begin{tabular}{|c|c|c|c|c|c|c|c|}
\hline $\begin{array}{c}\text { Chemical } \\
\text { composition }\end{array}$ & $\begin{array}{c}\text { Corn } \\
\text { grits }\end{array}$ & Barley & Chickpea & $\begin{array}{c}\text { Lettuce } \\
\text { seeds }\end{array}$ & $\begin{array}{c}\text { Cum } \\
\text { in }\end{array}$ & $\begin{array}{c}\text { Black } \\
\text { pepper }\end{array}$ & $\begin{array}{c}\text { Black } \\
\text { cumin }\end{array}$ \\
\hline Protein \% & 9.50 & 12.01 & 40.60 & 22.50 & 17.81 & 12.50 & 21.34 \\
Lipids \% & 0.94 & 2.75 & 19.50 & 7.50 & 2.27 & 3.30 & 3.55 \\
Crude fiber \% & 0.71 & 8.40 & 10.71 & 6.60 & 10.50 & 14.20 & 8.47 \\
Ash \% & 0.65 & 4.68 & 6.93 & 4.12 & 8.40 & 9.00 & 6.34 \\
Total carbohydrates\% & 88.20 & 72.16 & 22.26 & 59.28 & 61.02 & 61.00 & 60.30 \\
\hline
\end{tabular}

$3.55,3.30,2.75,2.27$ and $0.94 \%$, respectively. Crude fiber and ash were determined in raw materials and the results are reported in Table (2). The result showed that the black pepper, chickpea and cumin seeds had contained higher in crude fiber (14.20, 10.71 and 10.50 and respectively) followed by black cumin, barley and lettuce seeds were $8.47,7.40$ and $6.60 \%$, respectively. The crude fiber in corn grits was the lowest $0.71 \%$ compared with the other raw materials. The ash content in the raw materials was paralleled with crude fiber in raw materials. Total carbohydrates in the corn grits and barley were the highest ( 88.20 and $72.16 \%$ ) Cumin, black pepper, black cumin, lettuce seeds and chickpea were 61.02, 61.00, 60.30, 59.28 and $22.26 \%$, respectively. These results are agreement with those obtained with Kushi et al (1999) and Mothers (2002) Many researchers have studied the relationship between legume consumption and health benefits, such as, protection from cardiovascular disease, breast cancer, colon cancer, other cancers and diabetes. They found that Legumes are rich in complex carbohydrates and oligosaccharides, important components to human diet for keeping a healthy intestine flora (Wood and Grusak (2007) and Shad et al (2009) )

\section{Chemical composition of snacks prepared with different blends}

The results from chemical constituencies of the extrusion snack blends with lettuce seeds are reported in Table (3). From the results in Table (3) it could be notice that the extrusion snack blends. With lettuce seeds showed that the protein content in group (2) (blend 4, 5 and 6) were 15.04, 16.44 and $17.82 \%$ respectively main while the protein content in blends 1, 2, 3. Were (1) had contained $14.51,16.09$ and $17.49 \%$ respectively while control snack made from corn grits $(9.24 \%)$. Moreover, the groups (3and 4) were decreased slightly in protein content than groups 2 and 1) and it was ranged from $14.49,14.84$ to $17.29,17.64 \%$, respectively and also the groups (5 and 6) were the lowest (see Table 3) in protein content compared with other groups these may be attributed to increasing the content of chickpea .Generally these was no significant difference were noticed between all blends in these protein content.

Total lipids, crude fiber and ash content were gradually decreased in the snack blends from group (1) $4.02,4.87$ and $5.72 \%$ and the highest value of total lipids were noticed in group 2 which contained $4.23,5.08$ and $5.93 \%$, respectively. The groups' 5 and 6 were slightly lower and ranged from 3.62 and 3.83 to 5.32 and $5.53 \%$, respectively than other groups and control snack had contained $1.15 \%$. Whereas, the groups 3 and 4 were medium results in total lipids for the extrusion snack blends.

From Table (3). These in no significant different in total carbohydrate content in blends No., 1,4,7,8,10,11,13,14,16 and 17.

As gradually, increasing in total carbohydrates caused by the gradually decreased in protein content and total lipid and increased in crude fiber and ash content, respectively, in the snack blends as well as the control snack was the highest in total carbohydrates may be the lowest in protein content, total lipid, crude fiber and ash content than other groups.

Most snack foods produced today consist of starch from cereals, tubers or roots. However, in different countries, popular snacks are already enriched with protein from animal or vegetable origin (Suknark, 1998). However, vegetable proteins are less expensive and can be produced everywhere on earth provided there is some availability of water. Chickpea (Liu, 1997) is excellent sources of proteins that can be used to fortify starch-based snacks. 
Table 3. Chemical composition of product from the extrusion snack blends with lettuce seeds at zero time

\begin{tabular}{|c|c|c|c|c|c|c|}
\hline Groups & $\begin{array}{l}\text { Different } \\
\text { blends }\end{array}$ & $\begin{array}{c}\text { Protein } \\
\%\end{array}$ & $\begin{array}{l}\text { Lipids } \\
\%\end{array}$ & $\begin{array}{c}\text { Crude fiber } \\
\%\end{array}$ & $\begin{array}{c}\text { Ash } \\
\%\end{array}$ & $\begin{array}{c}\text { Total } \\
\text { carbohydrates } \\
\%\end{array}$ \\
\hline \multicolumn{2}{|c|}{ Control } & $9.24 \pm 1.04 b$ & $1.15 \pm 0.54 d$ & $1.38 \pm 0.37 c$ & $0.95 \pm 0.04 c$ & $87.28 \pm 5.47 \mathrm{a}$ \\
\hline \multirow{3}{*}{1} & 1 & $14.40 \pm 1.38 \mathrm{a}$ & $3.80 \pm 0.68 c$ & $5.66 \pm 0.91 \mathrm{a}$ & $3.71 \pm 0.54 \mathrm{a}$ & $72.43 \pm 4.12 b$ \\
\hline & 2 & $15.98 \pm 1.72 \mathrm{a}$ & $4.65 \pm 0.62 b$ & $5.81 \pm 0.95 a$ & $3.83 \pm 0.49 a$ & $69.73 \pm 5.27 c$ \\
\hline & 3 & $17.38 \pm 1.56 \mathrm{a}$ & $5.50 \pm 0.57 \mathrm{a}$ & $5.96 \pm 0.83 \mathrm{a}$ & $3.94 \pm 0.29 a$ & $67.22 \pm 6.58 \mathrm{c}$ \\
\hline \multirow{3}{*}{2} & 4 & $14.93 \pm 1.58 \mathrm{a}$ & $4.01 \pm 0.43 b$ & $5.84 \pm 0.76 \mathrm{a}$ & $3.80 \pm 0.25 a$ & $71.42 \pm 4.38 b$ \\
\hline & 5 & $16.33 \pm 1.39 a$ & $4.86 \pm 0.38 b$ & $5.99 \pm 0.84 a$ & $3.91 \pm 0.27 \mathrm{a}$ & $68.91 \pm 6.82 \mathrm{c}$ \\
\hline & 6 & $17.73 \pm 1.94 \mathrm{a}$ & $5.71 \pm 0.46 \mathrm{a}$ & $6.14 \pm 0.58 \mathrm{a}$ & $4.03 \pm 0.31 \mathrm{a}$ & $66.39 \pm 7.16 \mathrm{c}$ \\
\hline \multirow{3}{*}{3} & 7 & $14.38 \pm 1.27 \mathrm{a}$ & $3.60 \pm 0.28 c$ & $4.93 \pm 0.73$ & $3.31 \pm 0.39 a$ & $73.78 \pm 7.28 b$ \\
\hline & 8 & $15.78 \pm 1.68 \mathrm{a}$ & $4.45 \pm 0.39 b$ & $5.08 \pm 0.45 a$ & $3.43 \pm 0.37 \mathrm{a}$ & $71.26 \pm 6.28 b$ \\
\hline & 9 & $17.18 \pm 2.04 \mathrm{a}$ & $5.30 \pm 0.48 \mathrm{a}$ & $5.23 \pm 0.52 \mathrm{a}$ & $3.54 \pm 0.34 \mathrm{a}$ & $68.75 \pm 7.81 \mathrm{c}$ \\
\hline \multirow{3}{*}{4} & 10 & $14.73 \pm 1.68 \mathrm{a}$ & $3.81 \pm 0.34 c$ & $5.12 \pm 0.59 \mathrm{a}$ & $3.40 \pm 0.40 \mathrm{a}$ & $72.94 \pm 8.23 b$ \\
\hline & 11 & $16.13 \pm 2.01 \mathrm{a}$ & $4.66 \pm 0.48 b$ & $5.26 \pm 0.73 a$ & $3.51 \pm 0.38 a$ & $70.44 \pm 6.58 b$ \\
\hline & 12 & $17.53 \pm 2.12 \mathrm{a}$ & $5.51 \pm 0.54 \mathrm{a}$ & $5.41 \pm 0.83 \mathrm{a}$ & $3.63 \pm 0.29 a$ & $67.92 \pm 8.27 c$ \\
\hline \multirow{3}{*}{5} & 13 & $14.18 \pm 1.68 \mathrm{a}$ & $3.40 \pm 0.28$ & $4.20 \pm 0.46 \mathrm{~b}$ & $2.91 \pm 0.21$ & $75.31 \pm 9.01 \mathrm{~b}$ \\
\hline & 14 & $15.58 \pm 1.89 a$ & $4.25 \pm 0.29 b$ & $4.35 \pm 0.58 b$ & $3.03 \pm 0.18 \mathrm{a}$ & $72.79 \pm 8.13 b$ \\
\hline & 15 & $16.98 \pm 1.57 \mathrm{a}$ & $5.10 \pm 0.38 \mathrm{a}$ & $4.80 \pm 0.53 b$ & $3.14 \pm 0.22 \mathrm{a}$ & $69.98 \pm 7.11 \mathrm{c}$ \\
\hline \multirow{3}{*}{6} & 16 & $14.53 \pm 1.48 \mathrm{a}$ & $3.61 \pm 0.34 c$ & $4.38 \pm 0.48 b$ & $3.00 \pm 0.19 a$ & $74.48 \pm 6.88 b$ \\
\hline & 17 & $15.93 \pm 1.63 \mathrm{a}$ & $4.46 \pm 0.43 b$ & $4.43 \pm 0.73 b$ & $3.12 \pm 0.34 \mathrm{a}$ & $72.06 \pm 9.17 b$ \\
\hline & 18 & $17.33 \pm 2.18 \mathrm{a}$ & $5.31 \pm 0.58 \mathrm{a}$ & $4.68 \pm 0.29 b$ & $3.23 \pm 0.28 \mathrm{a}$ & $69.45 \pm 8.35 c$ \\
\hline
\end{tabular}

The same letters in the Colum had no significant difference (mean \pm SE)

\section{Physical characteristics of extruded snacks blend}

The physical characteristics such as color, water absorption index (WAI) and water soluble index (WSI) in control and their extruded blends with lettuce seeds and the results are presented in Table (4). Color is a prime factor in judging snacks products quality. The consumers select snacks products for appearance, with the judgment based on the brightness of the color. The results in Table (4) showed Hunter color values of snacks control and its extruded different blends with lettuce seeds. Group (6) (blend 16, 17 and 18) prepared with $60 \%$ corn grits and 15,10 and $5 \%$ barley and also $6 \%$ lettuce seeds showed that higher in lightness ( $\mathrm{L}$ value) and yellowness (b value) till $15 \%$ chickpea and nearly control snacks followed by group (5) (blend No., 13, 14 and 15) made from
$60 \%$ corn grits and 20, 15 and $10 \%$ barley and also till $15 \%$ chickpea plus $4 \%$ lettuce seeds gave the best results for lightness ( $L$ value) and yellowness (b value). The gradually decreased color in groups 3 and 4 followed by group (1) and group (2), respectively. From the obtained results, it could be noticed that the lightness ( $L$ value) and yellowness (b value) were decreased after increasing of chickpea and barley concentrations may be caused the barley and chickpea had contained the highest amount from total dietary fiber and crude fiber. These results are an agree ment with Ismail et al (2008) Color is an important characteristic of extruded foods. Color changes can provide information about the extent of browning reactions such as caramelization, Millard reaction, degree of cooking and pigment degradation that take place during the extrusion process (Altan et al 2008). Water absorption index (WAI) was used to assess this 
Table 4. Physical characteristics of extrusion snack blends with lettuce seeds.

\begin{tabular}{|c|c|c|c|c|c|c|}
\hline \multirow[t]{2}{*}{ Groups } & \multirow{2}{*}{$\begin{array}{c}\text { Different } \\
\text { blends }\end{array}$} & \multicolumn{3}{|c|}{ Color } & \multirow{2}{*}{ WAI $^{*}$} & \multirow{2}{*}{ WSI* } \\
\hline & & $\mathbf{L}$ & $\mathbf{a}$ & b & & \\
\hline \multicolumn{2}{|c|}{ Control } & $88.14 \pm 2.18 \mathrm{a}$ & $8.97 \pm 0.15 a$ & $35.71 \pm 0.91 \mathrm{a}$ & $3.30 \pm 0.08 d$ & $3.00 \pm 0.07 b$ \\
\hline \multirow[t]{3}{*}{1} & 1 & $77.29 \pm 1.99 b$ & $7.95 \pm 0.17 b$ & $25.35 \pm 0.93 b$ & $6.12 \pm 0.14 \mathrm{a}$ & $5.11 \pm 0.11 \mathrm{a}$ \\
\hline & 2 & $78.26 \pm 1.78 b$ & $8.14 \pm 0.19 a$ & $27.76 \pm 0.85 b$ & $5.99 \pm 0.16 b$ & $4.95 \pm 0.14 a b$ \\
\hline & 3 & $78.51 \pm 1.77 b$ & $8.21 \pm 0.21 \mathrm{a}$ & $27.26 \pm 0.87 b$ & $5.97 \pm 0.11 b$ & $4.92 \pm 0.09 a b$ \\
\hline \multirow[t]{3}{*}{2} & 4 & $79.43 \pm 1.75 b$ & $8.26 \pm 0.16 \mathrm{a}$ & $28.32 \pm 0.86 b$ & $5.82 \pm 0.14 b$ & $4.73 \pm 0.12 a b$ \\
\hline & 5 & $79.64 \pm 1.74 b$ & $8.32 \pm 0.24 \mathrm{a}$ & $28.54 \pm 0.92 b$ & $5.80 \pm 0.17 b$ & $4.45 \pm 0.15 a b$ \\
\hline & 6 & $80.42 \pm 2.04 \mathrm{a}$ & $8.43 \pm 0.28 \mathrm{a}$ & $29.76 \pm 0.94 b$ & $5.73 \pm 0.16 b$ & $4.42 \pm 0.13 \mathrm{ab}$ \\
\hline \multirow[t]{3}{*}{3} & 7 & $82.41 \pm 2.24 \mathrm{a}$ & $8.59 \pm 0.25 \mathrm{a}$ & $29.38 \pm 0.79 b$ & $5.65 \pm 0.09 b$ & $4.21 \pm 0.07 \mathrm{ab}$ \\
\hline & 8 & $83.32 \pm 2.65 \mathrm{a}$ & $8.65 \pm 0.29 a$ & $30.28 \pm 0.98 a$ & $5.59 \pm 0.17 b$ & $4.12 \pm 0.14 a b$ \\
\hline & 9 & $83.44 \pm 2.86 \mathrm{a}$ & $7.70 \pm 0.17 b$ & $31.87 \pm 0.86 \mathrm{a}$ & $5.42 \pm 0.12 b$ & $4.00 \pm 0.08 \mathrm{ab}$ \\
\hline \multirow[t]{3}{*}{4} & 10 & $83.78 \pm 2.37 \mathrm{a}$ & $8.75 \pm 0.31 a$ & $31.29 \pm 0.90 \mathrm{a}$ & $5.27 \pm 0.11 b$ & $3.98 \pm 0.09 b$ \\
\hline & 11 & $83.78 \pm 2.37 \mathrm{a}$ & $8.75 \pm 0.30 \mathrm{a}$ & $31.29 \pm 0.82 \mathrm{a}$ & $5.02 \pm 0.07 b$ & $3.95 \pm 0.04 b$ \\
\hline & 12 & $84.55 \pm 3.01 \mathrm{a}$ & $8.81 \pm 0.29 a$ & $31.55 \pm 0.92 \mathrm{a}$ & $4.84 \pm 0.08 \mathrm{c}$ & $3.82 \pm 0.06 b$ \\
\hline \multirow[t]{3}{*}{5} & 13 & $84.71 \pm 3.08 \mathrm{a}$ & $8.84 \pm 0.34 \mathrm{a}$ & $31.53 \pm 0.76 \mathrm{a}$ & $4.72 \pm 0.06 \mathrm{c}$ & $3.71 \pm 0.05 b$ \\
\hline & 14 & $85.48 \pm 3.07 \mathrm{a}$ & $8.90 \pm 0.35 a$ & $32 . .47 \pm 0.79 a$ & $4.68 \pm 0.14 c$ & $3.64 \pm 0.11 b$ \\
\hline & 15 & $85.34 \pm 3.18 \mathrm{a}$ & $8.90 \pm 0.34 \mathrm{a}$ & $32.91 \pm 0.75 \mathrm{a}$ & $4.61 \pm 0.08 \mathrm{c}$ & $3.48 \pm 0.07 b$ \\
\hline \multirow[t]{3}{*}{6} & 16 & $85.32 \pm 3.54 \mathrm{a}$ & $8.88 \pm 0.38 \mathrm{a}$ & $32.37 \pm 0.69 \mathrm{a}$ & $4.45 \pm 0.13 c$ & $3.31 \pm 0.11 b$ \\
\hline & 17 & $85.32 \pm 3.82 \mathrm{a}$ & $8.88 \pm 0.37 a$ & $32.37 \pm 1.01 \mathrm{a}$ & $4.45 \pm 0.14 c$ & $3.31 \pm 0.12 b$ \\
\hline & 18 & $86.75 \pm 4.00 \mathrm{a}$ & $8.94 \pm 0.39 a$ & $33.56 \pm 1.12 \mathrm{a}$ & $4.25 \pm 0.16 c$ & $3.26 \pm 0.13 b$ \\
\hline
\end{tabular}

WAl: water absorption index, results expressed as weight of gel/gram of dry samples

WSI: water solubility index, result expressed as percent of dry solids in the supernatant.

Huntr color values: L: lightness, b: yellowness, a: redness

The same letters in the Colum has no significant difference (mean \pm SE)

quality factor and water solubility index (WSI) result expressed as percent of dry solids in the supernatant. Water absorption index and water solubility index were determined in the extrusion blends with lettuce seeds and the results are presented in Table (4). The obtained results from Table (4) show that the extrusion different snack blends with lettuce seeds were higher in water absorption index (WAI) than extrusion control. The highest water absorption index was in groups (1 and 2) (blends from No., 1 to 6 , respectively) made by increasing chickpea and barley followed by groups (3 and 4) whereas the groups (5 and 6 ) the extrusion different snack blends were nearly to extrusion of control. This may be attributed to the high proportion of gelatinized starch found in the extrusion blends. The results were in agreement with Debbouz (1992) Water soluble index (WSI) expresses the percentage of dry matter recovered after the su- pernatant is evaporated from the water absorption determination. The results in the Tables (5 and 6) showed that slightly difference in water soluble index (WSI) was found between the extrusion different blends prepared with lettuce seeds and also control snacks. Water soluble index (WAI) reflects the ability of starch to absorb water and is an indirect measure of the amount of intact and fully gelatinized starch granules. The increase in extrudates (WAI) with increasing in screw speed was attributed to an increase in starch gelatinization, (Colonna et al 1989 and Osman et al 2000).

\section{Texture profile parameter snack blends at zero time}

Data illustrated in Table (5), revealed that texture indices of extrusion snack blends (at zero time) prepared with corn grits, barley, chickpea, 

Herbs distributed in Egypt

cumin, black pepper, black cumin and lettuce seeds. From the results, it could be noticed that Hardness of extrusion snack blends with lettuce seeds were no significant deference in all blends. The lowest hardness value (5.31) was recorded for blend No., 18 in group 6 prepared with $5 \%$ barley at $60 \%$ corn grits and nearly the control 4.29 from these results, it could be notice that when corn grits increased and barley decreased the hardness was decreased and also equal control made from corn grits. Cohesiveness values ranged from $0.65 \%$ to $2.15 \%$ showed differences between different extrusion snack blends. The highest cohesiveness value was recorded for snack blend No., 1 in group 1 was prepared with $40 \%$ corn grits at $40 \%$ barley and $10 \%$ chickpea. On the contrary, no significant value were recorded for control made from corn grits and extrusion blends 15,17 and 18 in group 6 The slightly differences and gradually decrease were observed in cohesiveness between the groups $2,3,4$, and 5 , respectively but no significant value. Gumminess of different extrusion snack blends ranged from 2.21 to $20.50 \mathrm{~g}$ showed differences. Gumminess of extrusion snack blends was increased by reducing barley level. Extrusion snack blend prepared by $40 \%$ corn grits at $40 \%$ barley and $10 \%$ chickpea had higher $(20.50 \mathrm{~g})$ in Gumminess values than that prepared with $5 \%$ barley and $60 \%$ corn grits $2.21 \%$ and nearly or equal control $(2.19 \mathrm{~g})$ made from corn grits. The highest value was recorded in groups 1 and 2 for extrusion snack blends prepared with $40 \%$ corn grits and $40,35,30$ and $25 \%$ barley ranged from 11.82 to $20.50 \mathrm{~g}$ followed by extrusion snack blends was recorded in groups 3 and 4 prepared with $50 \%$ corn grits and $30,25,20$ and $15 \%$ barley ranged from 6.15 to $14.71 \mathrm{~g}$ with differences between them. On the other hand, no differences were recorded between extrusion snack blends in groups' No., 5 and 6 prepared with $60 \%$ corn grits and $50,15,10$ and $5 \%$ barley ranged from 5.31 to $8.14 \mathrm{~g}$, respectively. Chewiness value was recorded $1.31 \mathrm{~g} / \mathrm{mm}$ in control sample prepared with corn grits and the different extrusion snack blends were ranged from 1.56 to $17.13 \mathrm{~g} / \mathrm{mm}$ made from corn grits, barley, chickpea, lettuce seeds, black pepper, cumin and black cumin, respectively. Chewiness values were increased by barley replacers' percentages increment. Also different extrusion snack blends prepared with $40 \%$ corn grits, 40, 35, 30 and $25 \%$ barley and 10, 15 and $20 \%$ chickpea had higher chewiness values than that prepared with $60 \%$ corn grits and 20,15, 10 and 5\% barley and 10,15 and $20 \%$ chickpea. Meanwhile, differ- ent extrusion snack blends prepared with 50\% corn grits, 30, 25, 20 and $15 \%$ barley and 10, 15 and $20 \%$ chickpea had medium chewiness values.

Springiness value was recorded $0.60 \mathrm{~mm}$ in control sample prepared with corn grits and the different extrusion snack blends were ranged from 0.60 to $0.84 \mathrm{~mm}$ showed slightly differences between all different extrusion snack blends.

From the obviously results, it could be noticed the texture profile analyses in different extrusion snack blends with lettuce seeds showed that the groups 5 and 6 made from $60 \%$ corn grits and 20 , 15,10 and $5 \%$ barley and 10, 15 had contained the lowest total dietary fiber and crude fiber therefore these extrusion blends give the best results in the texture profile analyses. Moreover the groups 1 and 2 had contained the highest total dietary fiber and crude fiber and extrusion blends give the lowest results in the texture profile analyses followed by groups 3 and 4 give the medium results in the texture profile analyses.

Texture, defined as the sensory manifestation of food structure and the way in which this structure reacts to the forces applied, represents the junction of all the mechanical, geometric and superficial attributes of a product, sensed through mechanical, tactile, visual and hearing receptors (Szczesniak, 1963a). Moreover, texture can be related to the deformation, disintegration and flow of the food when a force is applied (Bourne, 2002).

\section{Sensory properties of snack blends}

Appearance, crispiness, mouth feel, flavor and overall acceptability of the extruded blends with lettuce seeds the control snack made from corn grits only were evaluated by ten sensory judge and the results are reported in Table (6). The results from sensory properties of extrusion snacks with lettuce seeds are reported in Table (6). From the resultant, it could be notice that the group (6) (blends No., 16, 17 and 18) consists of $60 \%$ corn grits plus 15,10 and $5 \%$ barley were added separately to 10,15 and $20 \%$ chickpea and it was mixed with $3 \%$ for each cumin, black pepper and black cumin, respectively were mixed with $6 \%$ lettuce seeds gave the best overall acceptability. The extrusion blend no., 18 made from $20 \%$ chickpea and $5 \%$ barley the highest acceptability (95\%) and nearly or equal control (96\%) followed by 10 and $15 \%$ chickpea plus 15 and $10 \%$ barley were gave 93.0 and $88.0 \%$ during overall acceptability. Black pepper as a spices had to play in enhancing 
Table 5. Texture profile analysis (TPA) in snack blends at zero time:

\begin{tabular}{|c|c|c|c|c|c|c|}
\hline Group & $\begin{array}{l}\text { Different } \\
\text { blends }\end{array}$ & Hardness (N) & $\begin{array}{c}\text { Cohesiveness } \\
\text { (\%) }\end{array}$ & $\begin{array}{c}\text { Gumminess } \\
\text { (g) }\end{array}$ & $\begin{array}{c}\text { Chewiness } \\
\text { (g/mm) }\end{array}$ & $\begin{array}{c}\text { Springiness } \\
(\mathrm{mm})\end{array}$ \\
\hline \multicolumn{2}{|c|}{ Control } & $4.29 \pm 1.11 \mathrm{c}$ & $0.51 \pm 0.08 c$ & $2.19 \pm 1.28 \mathrm{c}$ & $1.31 \pm 0.94 \mathrm{c}$ & $0.60 \pm 0.07 c$ \\
\hline \multirow{3}{*}{1} & 1 & $11.86 \pm 2.15 a$ & $2.15 \pm 1.03 \mathrm{a}$ & $20.50 \pm 3.25 \mathrm{a}$ & $17.13 \pm 3.58 \mathrm{a}$ & $0.84 \pm 0.08 a$ \\
\hline & 2 & $11.01 \pm 2.38 \mathrm{a}$ & $1.94 \pm 0.95 b$ & $18.60 \pm 3.11 b$ & $14.90 \pm 3.21 \mathrm{a}$ & $0.81 \pm 0.05 a$ \\
\hline & 3 & $10.06 \pm 1.98 \mathrm{a}$ & $1.73 \pm 0.35 b$ & $14.71 \pm 3.69 \mathrm{~b}$ & $12.67 \pm 2.48 \mathrm{a}$ & $0.78 \pm 0.06 \mathrm{~b}$ \\
\hline \multirow{3}{*}{2} & 4 & $11.00 \pm 2.57 \mathrm{a}$ & $1.95 \pm 0.28 b$ & $18.61 \pm 4.21 \mathrm{~b}$ & $14.91 \pm 3.27 \mathrm{a}$ & $0.81 \pm 0.02 \mathrm{a}$ \\
\hline & 5 & $10.00 \pm 1.99 a$ & $1.75 \pm 0.22 b$ & $14.72 \pm 2.35 b$ & $12.77 \pm 2.14 \mathrm{a}$ & $0.78 \pm 0.07 b$ \\
\hline & 6 & $9.13 \pm 1.87$ & $1.52 \pm 0.35 b$ & $11.82 \pm 3.26 b$ & $10.45 \pm 1.98 \mathrm{a}$ & $0.75 \pm 0.05 b$ \\
\hline \multirow{3}{*}{3} & 7 & $10.04 \pm 2.54 \mathrm{a}$ & $1.74 \pm 0.65 b$ & $14.71 \pm 3.56 b$ & $12.76 \pm 2.68 \mathrm{a}$ & $0.78 \pm 0.09 b$ \\
\hline & 8 & $9.11 \pm 2.15 \mathrm{ab}$ & $1.51 \pm 0.52 b$ & $11.81 \pm 3.17 b$ & $10.44 \pm 2.49 a$ & $0.75 \pm 0.08 b$ \\
\hline & 9 & $8.16 \pm 2.11 \mathrm{ab}$ & $1.31 \pm 0.43 b$ & $8.92 \pm 2.58 \mathrm{ab}$ & $8.23 \pm 2.64 \mathrm{ab}$ & $0.72 \pm 0.07 \mathrm{~b}$ \\
\hline \multirow{3}{*}{4} & 10 & $9.13 \pm 2.38 \mathrm{ab}$ & $1.52 \pm 0.48 b$ & $11.81 \pm 2.67 b$ & $12.44 \pm 2.86 \mathrm{a}$ & $0.75 \pm 0.02 b$ \\
\hline & 11 & $8.17 \pm 2.04 \mathrm{ab}$ & $1.32 \pm 0.61 b$ & $8.91 \pm 2.61 \mathrm{ab}$ & $8.22 \pm 2.61 \mathrm{ab}$ & $0.72 \pm 0.04 \mathrm{~b}$ \\
\hline & 12 & $7.24 \pm 1.57 \mathrm{ab}$ & $1.10 \pm 0.83 b$ & $6.15 \pm 2.14 \mathrm{ab}$ & $6.01 \pm 2.28 \mathrm{ab}$ & $0.69 \pm 0.06 c$ \\
\hline \multirow{3}{*}{5} & 13 & $8.14 \pm 2.57 \mathrm{ab}$ & $1.31 \pm 0.64 b$ & $8.92 \pm 2.65 a b$ & $8.23 \pm 2.27 \mathrm{ab}$ & $0.72 \pm 0.04 b$ \\
\hline & 14 & $7.20 \pm 2.16 \mathrm{ab}$ & $1.10 \pm 0.28 b$ & $6.16 \pm 2.18 \mathrm{ab}$ & $6.00 \pm 2.10 \mathrm{ab}$ & $0.69 \pm 0.06 c$ \\
\hline & 15 & $6.26 \pm 2.38 \mathrm{~b}$ & $0.89 \pm 0.11 \mathrm{c}$ & $4.12 \pm 1.98 b$ & $4.79 \pm 2.13 b$ & $0.66 \pm 0.04 \mathrm{c}$ \\
\hline \multirow{3}{*}{6} & 16 & $7.21 \pm 2.97 \mathrm{ab}$ & $1.11 \pm 0.35 b$ & $6.15 \pm 2.18 \mathrm{ab}$ & $6.00 \pm 2.08 \mathrm{ab}$ & $0.69 \pm 0.06 c$ \\
\hline & 17 & $6.27 \pm 2.86 b$ & $0.90 \pm 0.27 c$ & $4.11 \pm 2.17 b$ & $4.79 \pm 1.95 b$ & $0.66 \pm 0.03 c$ \\
\hline & 18 & $5.31 \pm 1.54 c$ & $0.65 \pm 0.09 c$ & $3.21 \pm 1.68 c$ & $2.56 \pm 0.98 c$ & $0.63 \pm 0.05 c$ \\
\hline
\end{tabular}

The same letters in the colum had no significant difference (mean $\pm S E$ )

Table 6. Sensory properties of snack blends at evaluation zero time

\begin{tabular}{|c|c|c|c|c|c|c|}
\hline Groups & $\begin{array}{c}\text { Different } \\
\text { blends }\end{array}$ & $\begin{array}{c}\text { Appearance } \\
\mathbf{( 2 5 )}\end{array}$ & $\begin{array}{c}\text { Crispiness } \\
\mathbf{( 2 5 )}\end{array}$ & $\begin{array}{c}\text { Mouth-fell } \\
\mathbf{( 2 5 )}\end{array}$ & $\begin{array}{c}\text { Flavor } \\
\mathbf{( 2 5 )}\end{array}$ & $\begin{array}{c}\text { Overall } \\
\text { acceptability } \\
\mathbf{( 1 0 0 )}\end{array}$ \\
\hline \multicolumn{2}{|c|}{ Control } & $24.0 \pm 2.13 \mathrm{a}$ & $24.0 \pm 2.45 \mathrm{a}$ & $24.0 \pm 2.14 \mathrm{a}$ & $24.0 \pm 3.15 \mathrm{a}$ & $96.0 \pm 10.24 \mathrm{a}$ \\
\hline \multirow{3}{*}{1} & 1 & $19.0 \pm 1.92 \mathrm{c}$ & $17.0 \pm 1.09 \mathrm{c}$ & $19.0 \pm 1.86 \mathrm{c}$ & $19.0 \pm 1.86 \mathrm{c}$ & $74.0 \pm 6.52 \mathrm{~b}$ \\
& 2 & $19.0 \pm 1.67 \mathrm{c}$ & $17.0 \pm 1.17 \mathrm{c}$ & $20.0 \pm 2.16 \mathrm{~b}$ & $19.0 \pm 1.67 \mathrm{c}$ & $75.0 \pm 5.84 \mathrm{~b}$ \\
& 3 & $19.0 \pm 1.83 \mathrm{c}$ & $17.0 \pm 1.34 \mathrm{c}$ & $20.0 \pm 2.62 \mathrm{~b}$ & $20.0 \pm 1.73 \mathrm{~b}$ & $76.0 \pm 6.73 \mathrm{~b}$ \\
\hline \multirow{3}{*}{2} & 4 & $19.0 \pm 1.59 \mathrm{c}$ & $18.0 \pm 1.57 \mathrm{~b}$ & $20.0 \pm 2.58 \mathrm{~b}$ & $20.0 \pm 2.54 \mathrm{~b}$ & $77.0 \pm 8.21 \mathrm{~b}$ \\
& 5 & $20.0 \pm 2.34 \mathrm{~b}$ & $18.0 \pm 1.82 \mathrm{~b}$ & $20.0 \pm 2.43 \mathrm{~b}$ & $20.0 \pm 2.19 \mathrm{~b}$ & $78.0 \pm 8.37 \mathrm{~b}$ \\
& 6 & $20.0 \pm 2.71 \mathrm{~b}$ & $18.0 \pm 1.11 \mathrm{~b}$ & $21.0 \pm 2.76 \mathrm{ab}$ & $20.0 \pm 2.68 \mathrm{~b}$ & $79.0 \pm 7.69 \mathrm{~b}$ \\
\hline \multirow{3}{*}{3} & 7 & $20.0 \pm 2.95 \mathrm{~b}$ & $19.0 \pm 2.38 \mathrm{ab}$ & $21.0 \pm 2.74 \mathrm{ab}$ & $20.0 \pm 2.23 \mathrm{~b}$ & $80.0 \pm 7.98 \mathrm{ab}$ \\
& 8 & $20.0 \pm 2.37 \mathrm{~b}$ & $19.0 \pm 2.19 \mathrm{ab}$ & $21.0 \pm 2.96 \mathrm{ab}$ & $21.0 \pm 2.94 \mathrm{ab}$ & $81.0 \pm 9.12 \mathrm{ab}$ \\
& 9 & $21.0 \pm 2.48 \mathrm{ab}$ & $19.0 \pm 2.21 \mathrm{ab}$ & $21.0 \pm 2.39 \mathrm{ab}$ & $21.0 \pm 2.38 \mathrm{ab}$ & $82.0 \pm 9.38 \mathrm{ab}$ \\
\hline \multirow{3}{*}{4} & 10 & $21.0 \pm 2.29 \mathrm{ab}$ & $19.0 \pm 2.38 \mathrm{ab}$ & $21.0 \pm 2.16 \mathrm{ab}$ & $21.0 \pm 2.86 \mathrm{ab}$ & $82.0 \pm 9.77 \mathrm{ab}$ \\
& 11 & $21.0 \pm 2.67 \mathrm{ab}$ & $20.0 \pm 2.47 \mathrm{ab}$ & $22.0 \pm 2.24 \mathrm{ab}$ & $22.0 \pm 2.41 \mathrm{ab}$ & $85.0 \pm 10.16 \mathrm{ab}$ \\
& 12 & $22.0 \pm 3.01 \mathrm{ab}$ & $19.0 \pm 2.68 \mathrm{ab}$ & $22.0 \pm 2.35 \mathrm{ab}$ & $23.0 \pm 3.01 \mathrm{a}$ & $86.0 \pm 10.28 \mathrm{ab}$ \\
\hline \multirow{3}{*}{5} & 13 & $22.0 \pm 2.38 \mathrm{ab}$ & $19.0 \pm 2.66 \mathrm{ab}$ & $22.0 \pm 2.87 \mathrm{ab}$ & $23.0 \pm 3.16 \mathrm{a}$ & $86.0 \pm 10.67 \mathrm{ab}$ \\
& 14 & $22.0 \pm 2.82 \mathrm{ab}$ & $21.0 \pm 2.53 \mathrm{a}$ & $22.0 \pm 2.59 \mathrm{ab}$ & $22.0 \pm 2.86 \mathrm{ab}$ & $87.0 \pm 10.38 \mathrm{ab}$ \\
& 15 & $22.0 \pm 3.12 \mathrm{ab}$ & $20.0 \pm 2.77 \mathrm{ab}$ & $22.0 \pm 2.79 \mathrm{ab}$ & $23.0 \pm 2,84 \mathrm{a}$ & $87.0 \pm 9.97 \mathrm{ab}$ \\
\hline \multirow{3}{*}{6} & 16 & $22.0 \pm 2.91 \mathrm{ab}$ & $21.0 \pm 2.52 \mathrm{a}$ & $23.0 \pm 2.45 \mathrm{a}$ & $23.0 \pm 2,98 \mathrm{a}$ & $89.0 \pm 10.57 \mathrm{ab}$ \\
& 17 & $23.0 \pm 2.83 \mathrm{a}$ & $21.0 \pm 2.95 \mathrm{a}$ & $23.0 \pm 2.46 \mathrm{a}$ & $24.0 \pm 3.12 \mathrm{a}$ & $91.0 \pm 11.11 \mathrm{a}$ \\
& 18 & $23.0 \pm 3.11 \mathrm{a}$ & $22.0 \pm 2.46 \mathrm{a}$ & $24.0 \pm 02.61 \mathrm{a}$ & $24.0 \pm 3.24 \mathrm{a}$ & $93.0 \pm 1.24 \mathrm{a}$ \\
\hline
\end{tabular}

The same letters in the column had no significant difference (mean \pm SE) 
the taste and flavor of the snack blends and cumin seeds were used as a spice for their special aromatic effect of the snack blends. Moreover, the group (5) (blend No., 13, 14 and 15) prepared with $60 \%$ corn grits and 20,15 and $10 \%$ barley were added separately to 10,15 and $20 \%$ chickpea and it was mixed with $2 \%$ for each cumin, black pepper and black cumin, respectively were mixed with $4 \%$ lettuce seeds and the results observed that 91,89 and $89 \%$ on overall acceptability. These results caused when the increased corn grits and decreasing fiber derived from barley and chickpea in the snacks blends, the overall acceptability was the best. The group (4) (blends No., 10, 11 and 12) consists of $50 \%$ corn grits plus 25,20 and $15 \%$ barley were added separately to 10,15 and $20 \%$ chickpea and it was mixed with $3 \%$ for each cumin, black pepper and black cumin, respectively were mixed with $6 \%$ lettuce seeds. The results from the same table illustrated that the group 4 at different levels from chickpea were 88.0, 87.0 and $85.0 \%$ on overall acceptability. As well as the group 3 (blends No., 7, 8 and 9) at different levels 10, 15 and $30 \%$ from chickpea plus 30, 25 and $20 \%$ barley and it was mixed with $2 \%$ for each cumin, black pepper and black cumin, respectively were mixed with $4 \%$ lettuce seeds were $85.0,83.0$ and $81.0 \%$ during overall acceptability. These results showed that medium acceptability may be corn grits and barley were medium weigh than groups' No. 5 and 6 and also chickpea was the same weigh in the groups. The group 2 (blends No., 4, 5 and 6) had contained $40 \%$ from corn grits was added separately to 10,15 and $20 \%$ chickpea plus $3 \%$ other ingredients and $6 \%$ lettuce seeds were mixed with 35,30 and $25 \%$ barley. Moreover, the group 1 (blends No., 1, 2 and 3) had contained 40\% from corn grits was added separately to 10,15 and $20 \%$ chickpea plus $2 \%$ other ingredients and $4 \%$ lettuce seeds were mixed with 40,35 and $30 \%$ barley. From the result, it could be noticed that the groups 1 and 2 were the overall acceptability of blends No., 7 to 18 had the no significance difference compared to control sample. These results are agreement with Singh et al (2003).

From the results it could be recommended that the different extrusion snack blends with lettuce seeds showed that the group's No., 5 and 6 incoroded from $60 \%$ corn grits and 20, 15, 10 and 5\% barley and $10,15 \%$ chickpea gave the best results. The conclusion from different obtained data showed that different samples of snack made from corn grits using other materials have high nutritive value, Sensory test and Statistical evaluations compared with those made from corn grits (100\%).

\section{REFERENCES}

Altan, A., McCathy, K.L. and Maskan, M. 2008. Twin-screw extrusion of barley-grape pomace belnds: extrudate characteristics and determination of optimum processing conditions. Journal of Food Engineering, 89(1), 24-32.

Anderson, R.N., Conway, H.F., Pfeifer, V.H. and Griffin, E.L. 1969. Gelatinization of corn grits by roll and extrusion cooking. Cereal Sci. Today, 14, 4-8.

AOAC 2005. Official Methods of Analysis of the Association of Official Agricultural Chemists Published by the association of official analytical Chemists Washington 25 p., D.C., U.S.A.

Ahmed, Z.S. 1999. Physico-chemical, structural and sensory quality of corn-based flax-snack. Nahrung 43(4), 253-258.

Bourne, M.C. 2002. Food Texture and Viscosity: Concept and Measurement, second ed. Academic Press, San Diego, 15 p.

Colonna, P.J., Tayeb, J. and Mercier, C. 1989. Extrusion cooking of starch and starchy products. In: Mercier, C., Linko, P., Harper, J.M (Eds.), Extrusion Cooking. American Association of Cereal Chemists, Inc., St. Paul, MN, pp. 219-247.

Debbous, A. 1992. Influence of raw material and processing on couscous quality. Ph.D. Thesis, North Dakota State Univ., Fargo, N D.

Francis, F.J. 1998. Clolur analysis in S. S. Nielson (ed), Food Analysis Maryland: Chapman and Hall.

Harper, J.M. 1981. Extrusion of Foods, Vol. 1, CRC Press, Inc. Boca Raton, FL.

Huber, G. 2001. Snack Foods from Cooking Extruders, pp. 1-33. In R.W. Lucas; L.W. Rooney (ed.), Snacks Food Processing, CRC Press, Inc., Boca Raton, FL.

Ismail, B., Haffar, I., Baalbaki, R. and Henry, J. 2008. Physico-chemical characteristics and sensory quality of two date varieties under commercial and industrial storage conditions. LWT 41, 896-904.

Kushi, L.H., Meyer, K.A. and Jacobs, D.R.J. 1999. Cereals, legumes, and chronic disease risk reduction: evidence from epidemiologic studies. Am. J. Clin. Nutr., 70, 451S-458S. 
Lee, S.C. and L. Prosky 1995. International surrevy on dietary fiber definition, analysis and materials, JAOAC., 78, 22-36 .

Liu, K. 1997. Chickpeas: Chemistry, Technology and Utilization. Book from International Thompson Publishing. Florence, KY, pp. 25113.

Loveday, S.M., Hindmarsh, J.P., Creamer, L.K. and Singh, H. 2010. Physicochemical changes in intermediate-moisture protein bars made with whey protein or calcium caseinate. Food Res. Int. 43(5), 1321-1328.

Gomez. K.A. and Gomez, A.A. 1984. Statistical procedure for agiculture research. John willy and sonc inc. U.S.A.

Mathers, J.C. 2002. Pulses and carcinogenesis: potential for the prevention of colon, breast and other cancers. Br. J. Nutr., 88, 273-279.

Nostro, A., Cellini, L., Bartolomeo, S.D., Campli, E.D., Grande, R., and Cannatelli, M.A. 2005. Antibacterial effect of plant extracts against Helicobacter pylori. Phytotherapy Research, 19, 198-202.

Nwabueze, T.U. 2007. Effects of process variables on trypsin inhibitor activity (TIA), phytic acid and tannin content of extruded african breadfruit-soy-corn mixtures: A response surface analysis. Journal of Food Science and Technology, 40(1), 21-29.

Nwabueze, T.U. and Iwe, M.O. 2010. Residence time distribution (RTD) in a single screw extrusion of African breadfruit mixtures. Food Bioprocess Technology, 3, 135-145.

Osman, M.G., Sahai, D. and Jackson, D.S. 2000. Oil absorption characteristics of a multigrain extrudate during frying: effect of extrusion temperature and screw speed. Cereal Chemistry, 77(2), 101-104.

Prosky, L., Asp, N.G., Schweizer, T.F., Devries, J.W. and Furda, I. 1988. Determination of insoluble and soluble and total dietary fiber in Food products: Inter Laboratory study. J. Assoc. off. Anal. Chem., 71, 1017 - 1023.

Raghavan, S. 2007. Handbook of spices, seasonings, and flavorings. 2nd Ed. CRC Press, Taylor \& Francis Group, Boca Raton.
Shad, M.A., Pervez, H., Zafar, Z.I., Zia-UI-Haq, M. and Nawaz, H. 2009. Evaluation of biochemical composition and physicoquemical parameters of oil from seeds of desi chickpea varieties cultivated in arid zone of Pakistan. Pakistan Journal of Botany, 41, 655-662.

Simões, C.M.D.O., Schenkel, E.P. and Gosmann, G. 2007. Farmacognosia: Da planta ao medicamento. 6th Edition, UFSC/UFRGS, Porto Alegre.

Singh, N., Singh, J., Kaur, K., Sodhi, N.S. and Gill, B.S. 2003. Morphological, Thermal and Rheological Properties of Starches from Different Botanical Sources, Food Chem., 81(2), 219- 231.

Suknark, K. 1998. Development of extrusion processes for novel snack food production and the physicochemical and nutritional properties of resulting products. Dissertation, Department of Food Science and Technology. University of Georgia, Athens, GA pp. 99-145.

Szczesniak, A.S. 1963. Classification of textural characteristics. Journal of Food Science, 28, 385-389.

Vanderzant, C. and Splittstoesser, D.F. 1992. Compendium of Methods for the Microbiological Examination of Foods, $3^{\text {rd }}$ edn. American Public Health Association, Washington, DC.

Wiedman, W. and Strobel, E. 1987. Processing and economic advantages of extrusion cooking in comparison with conventional processing in the food industry, pp 132-169. In C. O'Connor (ed.), Extrusion Technology for the Food Industry. Elsevier Applied science, New York, USA.

Wood, J.A. and Grusak, M.A. 2007. Nutritional value of chickpea. In: Yadav, S.S., Redden, B., Chen, W. and Sharma, B., Eds., Chickpea Breeding and Management, CAB International, Wallingford, pp. 101-142.

Yang, S.H. 2008. Effects of adlay species and rice flour ratio on the physicochemical properties and texture characteristic of adlay-based extrudates. Journal of Food Enginering, 84(3), 489-494.

Yilmaz, Y. and Toledo, R. 2005. Antioxidant activity of water-soluble Maillard Reaction Products. Food Chem., 93(2), 273-278. 